\title{
PROBLEMATIKA TINDAK PIDANA PERSETUBUHAN ANTARA ANAK LAKI-LAKI DENGAN ANAK PEREMPUAN
}

Oleh:

\author{
Ibnu Maulana Zahida \\ Email: Ibnu7maulana@gmail.com
}

Program Studi Magister Ilmu Hukum Universitas Airlangga

\author{
Arum Ayu Lestari \\ Email: Arumayu4@gmail.com \\ Program Studi Magister Ilmu Hukum Universitas Airlangga
}

Sindi Dwi Yunike

Email: sindiyunike712@gmail.com

\section{Dinas Pemberdayaan Perempuan Perlindungan Anak dan Keluarga Berencana Kabupaten Jember}

\begin{abstract}
Abstrak
Anak menjadi perhatian khusus di dalam hukum, dikarenakan anak tidak dapat melindungi dirinya sendiri, terutama dari berbagai macam kejahatan, dengan demikian anak juga wajib mendapatkan perlindungan hukum terhadap hak-haknya. Problematika di dalam hukum berkaitan dengan kesetaraan hukum antara anak laki-laki dengan anak perempuan yang melakukan persetubuhan atas kemauannya, karena banyak kita ketahui pertanggungjawaban dibebankan kepada pihak anak laki-laki saja, sedangkan anak perempuan dianggap korban. Pendekatan Ilmu Hukum yang digunakan dalam penelitian ini doctrical research, metode pendekatan konseptual serta pendekatan perundang-undangan.Akan menjadi sebuah konflik hukum ketika tindak pidana persetubuhan yang dilakukan oleh anak mendapatkan perlakuan yang berbeda sedangkan tindak pidana tersebut terjadi atas kemauan dari kedua belah pihak.
\end{abstract}

Kata kunci: Anak, Berhadapan dengan hukum, Kesetaraan

\begin{abstract}
The child is a particular concern in the law, because the child cannot protect itself, especially from all manner of evil, and thus the child is under obligation to obtain legal protection against his rights. Problematic in the law relates to the equality of the law between a boy and a girl who makes sexual intercourse upon his will, since many of us know to be accountable to the boys alone, while girls are being victimized. The legal approach is used in. The study provides the doctrical research, the conceptual approach, and the constitutional approach. It would be a legal conflict when sexual crimes committed by a child get different treatment while the crimes take place on both sides
\end{abstract}

Keywords: Child, Equality, Lawsuit 


\section{PENDAHULUAN}

\subsection{Latar Belakang}

Berbagai aturan hukum dibuat dan diatur sedemikian rupa, terutama kaitannya dengan perlindungan terhadap anak. Anak menjadi perhatian khusus di dalam hukum, dikarenakan anak tidak dapat melindungi dirinya sendiri, terutama dari berbagai macam kejahatan, dengan demikian anak juga wajib mendapatkan perlindungan hukum terhadap hak-haknya, yang nantinya anak dapat berkembang dengan baik sebagai penerus bangsa.

Berkaitan dengan hak anak, telah diatur di dalam Pasal 28 ayat (2) Undang-Undang Dasar Negara Republik Indonesia Tahun 1945 (selanjutnya disebut UUD 1945) yang menyatakan bahwa "Setiap anak berhak atas kelangsungan hidup, tumbuh dan berkembang serta berhak atas perlindungan dari kekerasan dan diskriminasi”. Pasal tersebut memberikan arti bahwa pentingnya Pendidikan dan perlindungan terhadap hakhak anak demi masa depan mereka, yang secara universal pun dilindungi dalam Universal Declaration of Human Right (UDHR) dan International on Civil and Political Rights (ICPR). Dalam UndangUndang Nomor 11 Tahun 2012 tentang Sistem Peradilan Pidana Anak (selanjutnya disebut UU SPPA) telah memberikan perlindungan kepada anak yang mempunyai permasalahan dengan hukum atau didalam istilah hukum UU SPPA disebut anak yang berhadapan dengan hukum, dimulai dari proses awal penanganan perkara sampai dengan hukuman. Yang dimaksud dengan anak adalah mereka yang berusia dua belas tahun tetapi belum menginjak usia delapan belas tahun, yang mana telah diatur dalam Pasal 1 angka 3 UU SPPA.

Anak yang berhadapan dengan hukum telah dijelaskan di dalam Pasal 1 angka 2 UU SPPA yakni anak yang berkonflik dengan hukum, anak yang menjadi korban tindak pidana, dan saksi tindak pidana. Terdapat dua kategori seorang anak yang membuat anak harus berhadapan dengan hukum, yaitu: ${ }^{1}$

1. Status Offence adalah perbuatan anak yang dianggap orang dewasa bukan merupakan sebuah kejahatan, misalnya membolos sekolah, kabur dari rumah, membantah.

2. Juvenile Deliquence adalah perbuatan anak yang menurut orang dewasa merupakan perbuatan melanggar hukum.

Dengan demikian anak dapat langsung berhadapan langsung dengan hukum, baik posisinya sebagai korban maupun menjadi saksi dalam suatu tindak pidana.

Kejahatan semakin berkembang dari masa ke masa. Salah satunya adalah kejahatan terhadap kesusilan, misalnya saja

Dony Pribadi, perlindungan terhadap anak berhadapan dengan hukum. Jurnal hukum Volkgesist vol 3 no 1 desember 2018. Hlm. 22 
seperti pemerkosaan, persetubuhan dan pencabulan. Perbuatan yang tidak hanya dilakukakan oleh orang dewasa, akan tetapi dapat juga dilakukan oleh seseorang yang masih dikategorikan sebagai anak-anak. Semakin maraknya kasus yang melibatkan pelaku anak menimbulkan kecemasan tersenidiri tidak hanya bagi keluarga, tetapi juga bagi masyarakat. Sebagaimanakita ketahui bahwa persetubuhan merupakan hal yang ditentang baik dalam ranah agama maupun kesusilaan, dan sangat mencemaskan apabila yang menjadi korban dari persetubuhan adalah anak yang psikologi dan gairah seksualnya belum sesempurna orang dewasa. Maka bisa saja akan menimbulkan trauma yang mendalam bagi si korban anak tersebut.

Dalam hal tindak pidana persetubuhan terhadap anak telah diatur dalam peraturan perundang-undangan, yaitu dalam Kitab Undang-Undang Hukum Pidana (KUHP) dan Undang-Undang Nomor 23 tahun 2002 tentang Perlindungan Anak (selanjutnya disebut UU Perlindungan Anak), Berdasarkan pasal 287 ayat (1) KUHP, "Persetubuhan adalah barangsiapa bersetubuh dengan seorang perempuan di luar perkawinan, yang diketahui atau sepatutnya harus diduganya, bahwa umurnya belum lima belas tahun atau jika umurnya tidak jelas, bahwa belum waktunya untuk kawin, diancam dengan pidana penjara paling lama sembilan tahun". Kemudian dalam UU
Perlindungan Anak dalam Pasal 81 juga telah diatur terkait persetubuhan terhadap anak, dengan demikian aturan di dalam KUHP sudah tidak dapat diberlakukan lagi terhadap pelaku anak, hal ini dikarenakan Indonesia menganut asas "lex speciali derogat legi generali" yang artinya aturan khusus mengesampingkan aturan yang bersifat umum. Disini UU Perlindungan Anak lebih khusus daripada KUHP.

Persetubuhan orang dewasa yang dilakukan atas dasar suka sama suka, menurut KUHP keduanya tidak dapat dipidana, sedangkan perzinahan antara laki-laki dan perempuan dalam KUHP dapat dipidana.

Dari penelitian terdahulu, penulis tidak menemukan judul yang serupa, namun menemukan beberapa penelitian yang berkaitan seperti Hanindyo Imam Hutomo "Tindak Pidana Persetubuhan Yang Dilakukan Oleh Anak Terhadap Anak" (2016), Risnawati “Tinjauan Yuridis Tindak Pidana Persetubuhan Terhadap Anak (2014), dan Hartina "tinjauan yuridis tindak pidana persetubuhan yang dilakukan dengan kekerasan oleh anak terhadap anak" (2018).

Dalam penelitian kali ini yang membedakan dengan penelitian sebelumnya adalah menggunakan konsep feminis (menyetarakan hak laki-laki dan perempuan). Penulis menitikberatkan pada tindak pidana persetubuhan yang dilakukan oleh anak laki-laki dan perempuan atas dasar 
suka sama suka. Akan tetapi terdapat diskriminasi yang mana anak laki-laki yang dipidana sedangkan anak perempuan tidak dipidana, padahal dalam kondisi suka sama suka baik anak laki-laki maupun perempuan mempunyai posisi yang sama yaitu sebagai anak, yang mempunyai hak dan derajat yang sama juga. Berdasarkan uraian latar belakang yang telah dijelaskan diatas, maka penulis tertarik untuk melakukan penelitian lebih lanjut lagi terkait kesetaraan terhadap anak yang berhadapan dengan hukum.

\subsection{Rumusan Masalah}

Berdasarkan uraian yang sudah dijelaskan diatas, rumusan masalah pertama, apakah persetubuhan anak laki-laki dengan anak perempuan atas dasar kemauan keduanya dapat disetarakan pertanggungjawabannya?. Kedua, apakah orang tua dapat dipidana atas kejahatan persetubuhan anaknya?

\section{METODE PENELITIAN}

Tipe penelitian hukum yang penulis gunakan adalah tipe penelitian Doctrical Research, yakni sebuah penelitian yang nantinya akan menghasilkan penjelasan secara sistematis terkait dengan aturan hokumnya, memberikan analisa-analisa yang berhubungan antar hukum, memberikan penjelasan dalam bidang-bidang yang sulit, dan terdapat kemungkinan untuk memprediksi perkembangan hukum yang akan datang. ${ }^{2}$

Pendekatan konseptual beranjak dari pandangan-pandangan dan doktrin-doktrin yang berkembang di dalam ilmu hukum, sehingga dapat menemukan ide-ide yang melahirkan pengertian-pengertian hukum, serta pendekatan yuridis normatif atau pendekatan perundang-undangan. Tipe penelitian dengan pendekatan perundangundangan adalah melakukan telaah terhadap seluruh regulasi atau ketentuan yang ada kaitannya dengan isu hukum yang sedang penulis lakukan penelitian. ${ }^{3}$ Diantaranya menganalisis peraturan perundang-undangan yang mengatur tentang anak.

Peneliti dalam penulisannya menggunakan bahan hukum primer yang berasal dari peraturan perundang-undangan dalam Tata Hukum Positif Indonesia dan juga bukubuku, jurnal atau sebagainya sebagai bahan hukum sekunder yang digunakan untuk menunjang penelitian yang dilakukan peneliti dalam tulisan ini.

Prosedur pengumpulan bahan hukum dalam penelitian ini diawali dengan bahan hukum primer dengan melakukan pemahaman terhadap peraturan perundang-undangan yang mendukung. Selanjutnya melakukan pengumpulan dan pengkajian

2 Peter Mahmud Marzuki, Penelitian Hukum, Kencana Prenadamedia Group, Jakarta, 2014, Hlm32

${ }^{3}$ Ibid, Hlm 36 
terhadap bahan hukum sekunder yakni yang berkaitan dengan, pandangan, teori maupun pendapat ahli.

\section{PEMBAHASAN}

\section{Kesetaraan Tindak Pidana Persetubu-} han Anak Laki-Laki Dengan Anak Perempuan Atas Dasar Kemauan Keduanya

Tindak pidana persetubuhan yang dilakukan anak dengan anak dilatarbelakangi oleh bererapa factor. Faktor-faktor tersebut dapat dilihat dari keadaankeluarga, teknologi, hubungan sosial maupun faktor dari pelaku maupun dari sisi korban itu sendiri. Dalam hal ini korban bisa menjadi peran aktif maupun pasif. Seperti halnya contoh ketika adanya suatu kasus anak perempuan korban yang berusia 12 tahun melakukan hubungan layaknya suami istri dengan pacarnya yang berusia 16 tahun yang awalnya anak perempuan menolak untuk melakukannya akan tetapi karena mendapat bujuk rayu secara terus menerus dari anak laki-laki tersebut akhirnya anak perempuan itu kemudian untuk melakukannya. Dari contoh ini bahwa si anak perempuan atau korban tidak memiliki kemampuan atau kontrol diri ketika menghadapi lawan jenis atau tidak berpikir secara rasional dalam menentukan sikap sehingga pada akhirnya menjadi korban kekerasan seksual. Dan dalam hal ini korban juga berperan terhadap terjadinya tindak pidana, dikarenakan me- nimbulkan efek merangsang terhadap pelaku untuk melakukan persetubuhan yang dapat mendorong anak perempuan tersebut menjadi korban.

Pelaku dan korban dalam sebuah kejahatan mempunyai kedudukan sebagai partisipan artinya baik pelaku maupun korban telah terlibat secara aktif atau pasif dalam sebuah kejahatan. Keduanya memiliki peran yang sama-sama penting dalam menentukan terjadinya suatu kejahatan. Adakalanya Korban menjadi faktor yang membentuk pelaku kejahatan melakukan kejahatan baik dengan disengaja ataupun tidak disengaja. Usaha pencegahan kejahatan terhadap anak baik sebagai pelaku ataupun korban merupakan usaha bersama pada setiap lapisan masyarakat. Pada dasarnya tingkat kejahatan persetubuhan terhadap anak baik sebagai pelaku atau korban banyak faktor penyebabnya. Peran keluarga, masyarakat dan negara sangat penting untuk mencegah atau menekan terjadinya persetubuhan terhadap anak.

Perbuatan anak yang bertentangan dengan hukum sesuai Pasal 1 ayat (3) Undang-Undang Nomor 11 Tahun 2012 tentang Sistem Peradilan Anak (UU SPPA) bahwa bagi anak yang berusia 12 tahun belum berusia 18 tahun yang di duga melakukan tindak pidana dapat dikenakan pertanggungjawaban pidana sesuai yang telah diatur dengan Undang-Undang tersebut. Pertanggungjawaban pidana menurut 
Simons adalah adanya keadaan psikis sehingga menimbulkan sebuah penerapan ketentuan pidana baik dari sudut pandang umum dan pribadi yang dianggap patut. Adanya perbuatan pidana didasari oleh asas legalitas, sedangkan dapat dipidananya adalah seseorang karena adanya asas kesalahan (Culpabilitas).

Pertanggungjawaban pidana dapat diberikan kepada anak yang sedang berkonflik dengan hukum. Sanksi pidana sesuai UUSPPA Pasal 71 terdiri dari pidana pokok dan pidana tambahan terdiri dari pidana peringatan, pidana dengan syarat (Pembinaan diluar lembaga, pelayanan masyarakat atau pengawasan), pelatihan kerja; pembinaan dalam lembaga dan penjara.tambahan terdiri dari: Perampasan keuntungan yang diperoleh dari tindak pidana dan pemenuhan kewajiban adat.

Dalam Pasal 81 ayat (2) UU SPPA mengatur berkaitan dengan pidana penjara bagi anak, yakni paling lama $1 / 2$ (satu perdua) dari maksimum ancaman pidana penjara bagi orang dewasa. Di dalam ayat (6) menjelaskan bahwa apabila tindak pidana yang dilakukan anak merupakan tindak pidana yang diancam dengan pidana mati atau seumur hidup maka dijatuhkan pidana penjara paling lama 10 tahun. Penyelesaian permasalahan berkaitan dengan Anak yang berkonflik dengan hukum adalah dengan diversi, hal tersebut sebagai bentuk atau upaya pemenuhan dan perlindungan hak-hak anak. Berdasarkan UU SPPA diversi diatur dalam Pasal 1 ayat (7). Diversi merupakan sebuah cara untuk mendapatkan keadilan yang dilakukan di luar pengadian.

Penulis rasa, tidaklah adil apabila pelaku tindak pidana persetubuhan antara anak dengan anak atas dasar kemauannya, kemudian yang dimintai pertanggung jawaban hanya anak laki-laki. Hal tersebut sama seperti orang dewasa yang belum menikah dan mereka tidak dapat dijatuhi pemidanaan. Untuk itu diperlukan anak perempuan dan anak laki-laki harus memiliki hak memperoleh perlindungan yang sama.

Saat ini kita dihadapkan oleh feminisme tentang "kesetaraan" dan "hak". Pada struktur kehidupan sehari-hari, tujuan feminis harus dimasukkan ke dalam hukum dan dapat ditegakkan. ${ }^{4}$ Feminisme tidak hanya bertujuan untuk menyetarakan hak perempuan dengan laki-laki saja, tetapi keduanya harus mempunyai hak yang sama.

Wendy W. Williams menuliskan Equal Treatment Theoryatau teori perlakuan yang sama adalah generalisasi berbasis jenis kelamin umumnya tidak memperbolehkan pembedaan yang berasal dari fisik seperti ukuran dan kekuatan, dari tugas peran budaya seperti pencari nafkah. ${ }^{5}$ Teori ini menyatakan semua pemberlakukan antara

\footnotetext{
${ }^{4}$ Nancy Levit and Robert R. M. Verchick, Feminist Legal Theory, New York University Press, New York, 2016, Hlm 12

${ }^{5}$ Ibid
} 
perempuan dan laki-laki haruslah sama. Wendy W. Williams tidak menunjukkan apakah teori Equal Treatment Theory berlaku untuk dewasa saja, atau berlaku untuk anak juga.

Ketidakasetaraan perlakuan hukum atas tindak pidana persetubuhan anak atas kemauannya menjadi polemik yang harus diperhatikan. Anak perempuan seringkali mendapat perlindungan hukum berupa jaminan sebagai ganti kerugian karena menjadi korban dari tindak pidana persetubuhan. Dan peristiwa ini sering terjadi dalam kasus tindak pidana persetubuhan anak. Jaminan tersebut seperti halnya rehabilitasi pemulihan nama baik atau keseimbangan batin, pemberian ganti rugi yang dapat berupa restitusi, kompensasi dan jaminan atau santunan kesejahteraan sosial dan sebagainya.

Begitupun juga dengan anak laki-laki yang dianggap pelaku (pelaku anak dianggap korban) tindak pidana persetubuhan atas kemauan keduangnya (anak laki-laki dan anak perempuan) juga diberikan kesempatan yang sama mendapatkan rehabilitasi dan jaminan kesejahteraan sosial. Tidak sepatutnya pelaku anak dipidana. Karena secara psikis mereka masih membutuhkan arahan dan bimbingan.
2. Pertanggungjawaban Orang Tua Terhadap Tindak Pidana Persetubuhan Yang Dilakukan Anak

Keluarga merupakan sebuah institusi terpenting yang berpengaruh bagi perkembangan anak dalam hal biologis maupun psikologisnya. Sehingga interaksi social berperan penting untuk membangun kepribadian anak. Max Weber menjelaskan bahwa tindakan interaksi social adalah Tindakan seorang individu yang dapat mempengaruhi indiviu-individu lainnya dalam lingkungan social. ${ }^{6}$ Hal tersebut senada dengan pendapat dari Selo Soemarjan, bahwa keluarga adalah hal yang paling dasar dan paling inti sebagai pendidikan pertama dan sifatnya alamiah. Dalam keluarga pula anak akan diberikan bekal ketika dia kelak tumbuh dewasa sehingga akan memahami Bahasa, adat istiadat dan kebudayaan dengan baik. ${ }^{7}$

Keluarga, dalam ranah terkecilnya adalah orang tua terutama ayah sangat berperan penting dalam mendidik keluarganya, seperti memberikan bimbingan, pemberian contoh dan juga sanksi, yang dapat diaplikasikan dalam wujud suatu pekerjaan rumah tangga, keagamaan maupun didalam kemasyarakatan, termasuk juga dalam hal interaksi dalam pendidikan keluarga. Me-

${ }^{6}$ Didik Hermawan, pengaruh interaksi sosial terhadap prestasi belajar,Share Social Work Jurnal, vol. 5, no. 1, 2009, Hlm.14

${ }^{7}$ Selo Soemarjan, Sosiologi Suatu Pengantar, Gajah. Mada Press, Yogyakarta, 1962, Hlm 127 
nurut Ki Hajar Dewantara, keluarga merupakan kumpulan dari individu yang didalamnya tercermin sebuah rasa pengabdian secara tulus, tanpa mengharapkan balasan apapun. Karena arti dari sebuah keluarga merupakan suatu hal yang penting bagi kehidupan manusia. ${ }^{8}$

Anak dan orang dewasa merupakan dua individu yang sangat berbeda terutama dalam segi karateristik sifatnya, dalam usia anak mereka berada dalam fase pencarian jati diri, sehingga faktor eksternal seperti lingkungan disekitarnya sangat berpengaruh bagi pribadi dari anak tersebut. Ketika dia berada di lingkungan yang buruk maka akan menimbulkan potensi terhadap anak tersebut untuk melakukan perbuatan penyimpangan terhadap hukum yang biasanya disebut dengan Juvenile delinquency atau delikuensi anak, atau kenakalananak yang berhadapan dengan hukum $(\mathrm{ABH}) . \mathrm{ABH}$ ini dapat dipengaruhi oleh beberapa faktor antara lain: adanya dampak negatif dari perkembangan pembangunan yang cepat, arus globalisasi dibidang teknologi, informasi dan komunikasi, Kemajuan dibidang ilmu pengetahuan dan teknologi, perubahan gaya dan cara hidup sebagai orang tua. ${ }^{9}$

Oleh sebab itu orangtua bertanggungjawab menjaga dan melindungi anak. Jika

${ }^{8}$ Ki Hajar Dewantara, Ilmu Pendidikan, Taman Siswa, Yogyakarta, 1961, Hlm 250

${ }^{9}$ Galuh Dwi Purnama Putra, Bentuk Pertanggungjawaban Hukum Orangtua terhadap Pelaku Anak dalam Kasus Kecelakaan Lalulintas Universitas Airlangga, Tesis, 2015, Hlm 4 terdapat anak melakukan hubungan seksual secara suka sama suka seharusnya orangtualah yang bertanggungjawab dari perbuatan anak tersebut. Selain itu akibat perkembangan teknologi yang begitu pesat memberikan ruang bagi anak untuk mengakses konten-konten pornografi. Hal tersebut menjadi salah satu kesalahan orang tua, yang tidak memberikan pengawasan dengan baik.

Suatu perbuatan pidana hanya menunjuk apa yang dilarang dan diancamnya perbuatan dengan pemidanaan sehingga orang yang melakukan tindak pidana dijatuhi pidana, sebagaimana diancamkan sesuai dengan kesalahan apa yang ia lakukan, sebab azas dalam pertanggungjawaban pidana menyatakan bahwa tidak dapat dipidana seseorang apabila didalam orang tersebut tidak ditemukan kesalahan (Geen straf zonder schuld; Actus non facit reum nisi mens sir rea).

Terdapat 2 (dua) syarat seseorang dapat dipidana yang menjadi satu keadaan, adanya unsur perbuatan melawan hukum dan perbuatan tersebut dapat dipertanggungjawabkan sebagai unsur kesalahan, yang diperkuat dengan alat bukti berdasarkan keyakinan hakim di depan pengadilan. Moeljatno, menyatakan bahwa orang tidak mungkin dipertanggungjawabkan (dijatuhi pidana) kalau dia tidak melakukan perbuatan pidana, tetapi meskipun melakukan perbuatan pidana tidak selalu dapat di- 
pidana. Dalam hal inilah, pemidanaan terhadap anak dapat dipertimbangkan. ${ }^{10}$

Pembaharuan hukum pidana Indonesia menjadi salah satu topik yang menarik dan sering dijadikan bahan diskusi bagi para pakar hukum di Indonesia. Gustav Radbruch mengatakan bahwa "Memperbaharui hukum pidana tidak berarti memperbaiki hukum pidana, akan tetapi menggantinya dengan yang lebih baik". Pembaharuan itu tidak selalu dikaitkan dengan adanya perubahan pada KUHP, pembaharuan ini diharapkan dapat bersifat menyeluruh tidak hanya ditinjau dari adanya pembaharuan KUHP.

Berdasarkan RKUHP selanjutnya disebut (Rancangan Kitab Undang-undang Hukum Pidana) tahun 2019 Pasal 37 huruf (b) berbunyi "Dimintai pertanggungjawaban atas Tindak Pidana yang dilakukan oleh orang lain.” sedangkan penjelasannya berbunyi "Ketentuan ini mengandung asas pertanggungjawaban pengganti (vicarious liability) yang memberikan ketentuan bahwa Setiap Orang bertanggung jawab terhadap perbuatan yang dilakukan oleh orang lain yang melakukan pekerjaan atau perbuatan untuknya atau dalam batas perintahnya, misalnya pimpinan perusahaan yang bertanggung jawab atas perbuatan bawahannya." Asas vicarious liability

\footnotetext{
${ }^{10}$ Barda NawawiArief, Kebijakan Legislatif Dalam Penanggulangan Kejahatan Dengan Pidana Penjara, Genta Publishing, Yogyakarta, 2010, Hlm 80-81
}

dalam RKUHP memang merupakan pengecualian dari asas "tiada pidana tanpa kesalahan" sekaligus merupakan wujud dari ide keseimbangan sekaligus pelengkap dari asas Geen Straft Zonder Schuld. ${ }^{11}$

Vicarious liabilitymerupakan suatu perbuata yang pertanggung-jawabannya dibebankan kepada seseorang akibat dari perbuatan orang lain (the legal responsibility of one person for the wrongful acts of another). Menurut Barda Nawawi Arief, vicarious liability adalah sebuah konsep dibebankannya pertanggung jawaban seseorang dikarenakan kesalahan orang lain, misalnya seperti perbuatan yang dilakukan yang masih berada dalam lingkup pekerjaannya (the legal responsibility of one person for wrongful acts of another, as for example, when the acts are done within scope of employment).

Dalam kamus Henry Black (1979) vicarious liability diartikan sebagai berikut sebagai Indireect legal responsibility; for example, The liability of an employer for the acts of an employee, of a principle for torts and contracts of an agent (pertanggungjawaban majikan atas tindakan dari pekerja; atau pertanggungjawaban principal terhadap tindakan agen dalam suatu kontrak).

Vicarious liabilitymerupakan asas yang dikenal dalam hukum perdata, kemudian

\footnotetext{
${ }^{11}$ Sudarto, Hukum dan Hukum Pidana, Alumni, Bandung, 1986, Hlm 28
} 
diadopsi kedalam praktik hukum pidana. Ketentuan ini misalnya dapat dilihat dalam hukum Pasal 1367 KUHPer (Kitab Undangundang Hukum Perdata) yang berbunyi: "Setiap orang tidak saja bertanggung jawab untuk kerugian yang disebabkan karena perbuatannya sendiri tetapi juga untuk kerugian yang disebabkan karena perbuatan orang-orang yang menjadi tanggungannya, atau disebabkan oleh barang-barang yang berada dibawah pengawasannya".

Berdasarkan pasal tersebut bahwa vicarious liability dapat timbul dalam hubungan-hubungan sebagai berikut ;

a. Orang tua atau wali bertanggungjawab atas perbuatan yang dilakukan anaknya sebelum anak tersebut menginjak dewasa;

b. Majikan bertanggungjawab terhadap kerugian akibat perbuatan yang dilakukan oleh karyawannya; dan

c. Pertanggungjawaban guru-guru sekolah atas dampak dari perbuatan muridmuridnya.

Di Indonesia, vicarious liability lebih dikenal sebagai pertanggungjawaban korporasi, namun dalam perjalanan RKUHP juga mengadopsinya dan telah diakomodir kedalam Pasal 37 huruf (b) yang sudah dipaparkan diatas. Vicarious liability merupakan pengecualian dari asas "tiada pidana tanpa kesalahan" sekaligus merupakan wujud dariide keseimbangan sekaligus pelengkap (complement) dari asas Geen
Straft Zonder Schul.

Anak yang berada dibawah pengawasan orangtua, ketika anak melakukan tindak pidana kesusilaan, orangtua dari si anak dapat dimintai pertanggungjawaban pidana. Dasar dari adanya pertanggungjawaban pidana orang tua atas perbuatan anaknya berkaitan denganPasal 20 Undang-Undang Nomor 35 Tahun 2014 Tentang Perubahan Atas Undang-Undang Nomor 23 Tahun 2002 Tentang Perlindungan Anak, bahwa Negara, Pemerintah, Pemerintah Daerah, Masyarakat, Keluarga, dan Orang Tua atau Wali berkewajiban dan bertanggung jawab terhadap penyelenggaraan Perlindungan Anak dan pasal 9 Undang-Undang Nomor 4 Tahun 1979 tentang Kesejahteraan Anak, berdasarkan hal tersebut maka orang tua merupakan orang yang paling berpengaruh terhadap kesejahteraan anak-anaknya, baik secara rohani, jasmani maupun sosial.

\section{KESIMPULAN}

Berdasarkan permasalahan diatas kesetaraan terhadap tindak pidana persetubuhan anak perlu diatur lebih lanjut di dalam undang-undang. Dan orangtua tidak dapat menggantikan pertanggungjawaban pidana yang dijatuhkan terhadap anak meskipun orang tua menjadi salah satu faktor yang penting dalam tumbuh dan berkembangnya anak berkaitan pula dengan sikap dan karakter dari anak tersebut. 


\section{DAFTAR PUSTAKA}

\section{Buku dan Jurnal}

Arief, Barda Nawawi, Kebijakan Legislatif Dalam Penanggulangan Kejahatan Dengan Pidana Penjara, cetakan kedua, Genta Publishing, Yogyakarta, 2010.

Dewantara, Ki Hajar, Ilmu Pendidikan, cetakan pertama, Taman Siswa, Yogyakarta, 1961.

Hermawan, Didik, Pengaruh Interaksi Sosial Terhadap Prestasi Belajar, Share Social Work Jurnal, vol. 5, no. 1, 2009,

Levit, Nancy and Robert R. M. Verchick, Feminist Legal Theory, first edition, New York University Press, New York, 2016.

Marzuki, Peter Mahmud, Penelitian Hukum, cetakan kedua, Kencana Prenadamedia Group, Jakarta, 2014.

Pribadi, Dony, "Perlindungan terhadap anak berhadapan dengan hukum", Jurnal hukum Volkgesist, Volume 3 Nomor 1, desember 2018.
Putra, Galuh Dwi Purnama, Bentuk Pertanggungjawaban Hukum Orangtua terhadap Pelaku Anak dalam Kasus Kecelakaan Lalulintas, Universitas Airlangga, Tesis, 2015,

Selo Soemarjan, Sosiologi Suatu Pengantar, cetakan pertama Gajah. Mada Press, Yogyakarta, 1962.

Sudarto, Hukum dan Hukum Pidana, cetakan pertama, Alumni, Bandung, 1986.

\section{Peraturan Perundang-undangan}

Undang-undang Dasar tahun1945

Kitab Undang-Undang Hukum Pidana

Undang-Undang Nomor 23 tahun 2002 tentang Perlindungan Anak

Undang-Undang Nomor 11 Tahun 2012 tentang Sistem Peradilan Pidana Anak 
BIODATA SINGKAT PENULIS

Ibnu Maulana Zahida, S.H., beralamat di Jalan. Menak Sopal, Gang. 07, Desa Karangsoko, Kecamatan Trenggalek, Kabupaten Trenggalek. Menempuh Pendidikan tinggi sarjana S1 ilmu Hukum di Fakultas Hukum Universitas Jember lulus pada tahun 2019. Saat ini tengah menyelesaikan pendidikan program Magister Hukum di Fakultas Hukum Universitas Airlangga Surabaya.

Arum Ayu Lestari, S.H., beralamat di Dusun Darungan RT. 01, RW. 03 Desa Tegalarum Kecamatan Sempu Kabupaten Banyuwangi. Menempuh Pendidikan tinggi sarjana S1 ilmu Hukum di Fakultas Hukum Universitas Jember lulus pada tahun 2019. Saat ini tengah menyelesaikan pendidikan program Magister Hukum di Fakultas Hukum Universitas Airlangga Surabaya.
Sindi Dwi Yunike, S.H., beralamat di Dusun Watu-Ulo Desa Sumberrejo, Ambulu Jember. Menempuh Pendidikan tinggi sarjana S1 Ilmu Hukum Fakultas Hukum Universitas Negeri Jember lulus pada tahun 2019. Pada saat ini sedang bekerja sebagai Pendamping di Pusat Pelayanan Terpadu (P2TP2A) Dinas Pemberdayaan Perempuan Perlindungan Anak dan Keluarga Berencana di Kabupaten Jember. 